International Journal of Child, Youth and Family Studies (2015) 6(3): 440-457

\title{
FARMING FAMILIES AS FOSTER FAMILIES: THE FINDINGS OF AN EXPLORATORY STUDY ON CARE FARMING IN SWITZERLAND
}

\author{
Clara Bombach, Renate Stohler, and Hans Wydler
}

\begin{abstract}
The terms "care farming” and "social agriculture" are used to describe the foster care that farming families provide to children, adolescents, and adults. Whereas some European countries have national systems that provide support for care farming, little is known about care farmers in Switzerland. Best estimates show that at least one percent of all agricultural family operations provide care services in Switzerland; accordingly, care farming is a component of Swiss foster care. Against the background of the recent revision of the Child and Adult Protection Act [Kindes- und Erwachsenenschutzgesetz] and of legal provisions in relation to foster care, a qualitative system analysis was carried out in three cantons in 2013. The aim of the system analysis was to describe the context and importance of care farming and to identify the attitudes and working methods of both child and adult protection authorities and family placement organizations in relation to placements in agriculture. As part of the study, documents were analyzed and expert interviews were held with representatives of both groups. The interviewed representatives of the placement authorities regard placements in agriculture as a viable option, in particular for adolescents, if the match between the client and foster family is suitable. According to the surveyed family placement organizations, the interest among farming families in offering foster places is considerable. The study presents care farming as one care service within a complex support system for children and adolescents, and raises new questions for investigation by more detailed research projects.
\end{abstract}

Keywords: foster care, care farming, farming for health, green care, multifunctional farms, Switzerland

Clara Bombach, MA, is research associate at the School of Social Work, ZHAW Zurich University of Applied Sciences, Pfingstweidstrasse 96, P.O. Box 707, 8037 Zurich, Switzerland. Tel: (41) 5893489 53. E-mail: clara.bombach@zhaw.ch

Renate Stohler, is researcher and lecturer at the School of Social Work, ZHAW Zurich University of Applied Sciences, Pfingstweidstrasse 96, P.O. Box 707, 8037 Zurich, Switzerland. Tel: (41) 5893488 67. E-mail: renate.stohler@zhaw.ch

Hans Wydler, the Institute of Natural Resource Sciences of the School of Life Sciences and Facility Management, ZHAW Zurich University of Applied Sciences, Grüental, P.O. Box, 8820 Wädenswil, Switzerland. Tel: (41) 589345539.

E-mail: hans.wydler@zhaw.ch 
International Journal of Child, Youth and Family Studies (2015) 6(3): 440-457

In addition to their everyday activities as farmers many farming families throughout Europe perform social care services. So-called "social farmers" or "care farmers" take care of children and adolescents, disabled people, the elderly, and former drug addicts. The farmers share their family homes and working routines with their charges for short or extended periods of time. Whereas in countries such as Belgium and the Netherlands national systems to provide both professional and financial support for care-farming activities were established several years ago, little is known about care farmers in Switzerland. Wydler and Picard (2010) estimate that at least $1 \%$ of all agricultural family operations in the Swiss agriculture sector perform social care services; however, they assume that the actual number is significantly higher (Wydler, Widmer, \& Christ, 2010b). A qualitative research study by Wydler and Gairing (2010) found that care farmers described their work as particularly demanding in terms of workload, and psychologically challenging (see also Christ, Widmer, \& Wydler, 2010).

Although many farming families are clearly involved in the Swiss care sector, very little is known about how and with which target groups they perform their social activities, and how they are supported professionally and financially. A research project from the Zurich University of Applied Sciences, supported by the Federal Office for Agriculture, carried out a system analysis to identify the major players and administrative bodies in the field of care farming in Switzerland, and to identify questions for further research and in-depth investigation. The objective of this paper is to outline the findings of the study. The paper first introduces the field of care farming in general, comparing the development of care farming in Switzerland with that in other European countries. Then the study is described and its findings are presented in their particular Swiss context.

\section{Farming for Health: Green Care and Care Farming}

Many forms of nature therapy are subsumed under the concept of "farming for health". The term "green care”, which involves animal-assisted therapy and garden therapy, for example (Hassink \& van Dijk, 2006a; Hine, Peacock, \& Pretty, 2007; Hine, Peacock, \& Pretty, 2008; Sempik, Hine, \& Wilcox, 2010), is sometimes used synonymously with "farming for health". What links these services is that they enable participants to experience nature and create a focus on interaction with natural elements (Wiesinger, 2011): “Green Care farms represent a working environment where a diversity of target groups is performing meaningful activities” (Hassink \& van Dijk, 2006a). These educational, preventative healthcare, therapeutic, and rehabilitation methods include garden therapy, animal-assisted therapy, farm education, and other care farming methods (Hassink \& van Dijk, 2006b; Haubenhofer, Demattio, \& Geber, 2012; Wiesinger, 2011). Synonymous terms found in the literature include expressions like "social farming" and "green social work" (Limbrunner, 2003; Limbrunner \& van Elsen, 2013). The concept of care farming is also used in German-language discourse on the topic (Condrau et al., 2012; Haubenhofer et al., 2012; Wiesinger, 2011; Wydler \& Picard, 2010; Wydler et al., 2010b). 
International Journal of Child, Youth and Family Studies (2015) 6(3): 440-457

In this paper, we focus only on a specific aspect of farming for health: the type of care farming where children and adolescents are accommodated and looked after in farming families.

\section{Target groups}

Care farming benefits a variety of target groups, including disabled people, children and adolescents, former drug addicts, and elderly people with dementia (Driest, 2006; Hine et al., 2008). As Hassnik \& van Dijk (2006a) state: "Care farms can be a good provision for a diversity of target groups like people with mental problems, people with an addiction history, elderly people with dementia, autistic persons, long-term unemployed, people with burn-out and prisoners" (p. 350). There is a varying emphasis on particular focus groups in different European countries. For example, according to Hassink \& van Dijk (2006b), in Norway it is primarily psychiatric clients and children who are accommodated in the agricultural care sector, while in Sweden the majority of clients placed in agricultural settings are vulnerable children.

\section{Service types, duration of stay, reason for stay}

The services provided in the context of care farming range from short stays to long-term care (Driest, 2006). The duration of a person's placement in a farming family will differ according to the indication (reason for the stay) and the nature of the social service measure being implemented. For example, whereas elderly persons with dementia may live on a farm for several years, crisis interventions for adolescents may require stays of just a few weeks. Traditionally, studies carried out on care farming differentiate between long-term and short-term care (Kalisch \& van Elsen, 2007). One type of shortterm stay on farms, the "time-out", lasts only a few weeks to a few months. For example, a disruptive young person may be temporarily removed from school on a time-out, with the expectation of resuming attendance thereafter.

Care farming is thus a highly heterogeneous field, covering many different social activities and reaching a wide range of clients. An examination of concrete examples of care farming in different countries reveals further differences.

\section{Care farming in Europe}

Care farming has developed in different ways in different European countries (Hassink \& van Dijk, 2006b). Up to now, few general data have been available on care farming at the European level. This is due to the complexity of the services, their historically different developments and assessments, and structural differences. The services offered are managed through a variety of public structures. As a result, they vary widely in nature, and in the ways they are financed; moreover, often there are no organizations that arrange or survey the different green-care initiatives. In many cases, these social services have low visibility even in their own countries, and national regulations are often inadequate (Driest, 2006). Despite this, according to Hassink and van Dijk (2006a), an increase has been observed in the social agriculture sector throughout Europe. Forms of green care have already existed in Belgium for many decades. The first examples in northern European countries go back to 1930 (Goris \& 
International Journal of Child, Youth and Family Studies (2015) 6(3): 440-457

Dessein, 2007). In terms of the development and spread of these services, southern and eastern European countries are still in a "pioneering phase” (Driest, 2006, p. 102). These development trends will be dealt with selectively below.

Major differences can be observed throughout Europe with regard to activities, objectives, the nature of financing, the balance between care activities and agricultural production, and attitudes towards the target groups. Mayer \& van Elsen (2005) note this in the case of Germany, where green care services include organic teaching farms, facilities for people with disabilities, and addiction initiatives. Different services are offered for different target groups in Norway: "Care farms have developed as kindergartens and after-school clubs, provide activities for children with special needs or provide health and care options for psychiatric patients, those with learning difficulties and elderly people with dementia.” (Hine et al., 2008, p. 40). Green care has developed in very different directions in Great Britain "ranging from horticultural therapy, animalassisted therapy, pet therapy, ecotherapy, facilitated green exercise activities as a treatment option, and care farming” (Hine et al., 2007, p. 123).

In eastern Europe, Poland and Slovenia provide examples of the "pioneering phase". There are no statistics available on care farming in these countries and, instead of ministerial support, farming families in the green care sector have their own voluntary organizations and are often privately funded. Pawelczyk (2006) attributes the gap in the research on green care in Poland to the current lack of awareness among the Polish population of green care as a solution for social problems. As a result, up to now the activities in this area have been limited to small, isolated, self-financing projects that offer their own programmes. Vadnal (2007) describes care farming in Slovenia as similarly consisting of patchwork organizations, which are run on a voluntary and bottom-up basis and are not supported by specific policies or institutions (p. 11). When farmers in Slovenia were asked whether they could imagine providing services in the area of green care, $66 \%$ of the surveyed farming households reported that farmers generally knew too little about the topic of social farming (Vadnal, 2007). In Italy, green care activities are often supported by non-profit organizations such as social cooperatives or church organizations (Hine et al., 2008).

The situation in relation to care farming in the Netherlands is completely different. Wydler \& Picard (2010) refer to a "success story" here (p. 4). The number of farms that offer social services has been steadily increasing, not least because the Ministry of Agriculture, Nature, and Food Quality; the Ministry of Health; and the Ministry for Sport support these activities. Professionalization in the sector is also strongly supported, which could also be a factor in the rapid growth of care farming there (Hine et al., 2008). In Norway too, care farmers receive support from different ministries, for example the Ministry of Agriculture; the Ministry of Health, Social Affairs, Children and Family Affairs; and the Ministry of Education and Research. In addition to the ministries, local governments have established committees that support green care activities (Hine et al., 2008). The farms in Norway are involved in their municipalities and offer the services required by them. However, there are no statistics on the number of farms in Norway that provide social services (Haugan, Nyland, Fjeldavli, Meistad, \& Braastad, 2006). 
International Journal of Child, Youth and Family Studies (2015) 6(3): 440-457

\section{Research projects in Europe}

The Community of Practice (CoP) "Farming for Health"1 ${ }^{1}$ was established in 2004 to promote the exchange of information among European countries and record comparable data. The "COST Action 866 Green Care in Agriculture" ${ }^{2}$ project was also initiated in the context of calls for proposals for the Seventh EU Framework Programme (Braastad, Gallis, Sempic, Senni, \& van Elsen, 2007). An overview of the status of green care in different countries was developed as part of the COST Action and in the context of the CoP (Hassink \& van Dijk, 2006b). The focus was on social services in agriculture, on the one hand, and the field of green care in individual areas beyond the agriculture sector, on the other. The findings of the CoP Farming for Health conference of 2007 were published as conference proceedings by Dessein (2008). A project on social farming entitled So Far was carried out as part of the Sixth EU Framework Programme for Research and Technological Development. This project assessed the current situation of green care activities in eight European countries. These situational assessments are accompanied by implementation-oriented strategy forums and comparative strategy development (Di Iacovo \& O'Connor, 2009).

In recent years, numerous publications, including one by Limbrunner and van Elsen (2013), have explored the topic of care farming from different perspectives. Hence, interest in such services is clearly increasing, not only in relation to supply and demand, but also from the perspective of making a scientific contribution.

The evolution of the structures of social services in Swiss agriculture and how they compare to the above-presented developments in Europe are examined in greater detail in the next section.

\section{Established social service structures in Swiss agriculture}

Different forms of care services have been provided within the Swiss agriculture sector for a very long time and continue to be provided today, albeit in a different form. Traditional care services in agriculture constituted preliminary stages in the development of the welfare state, social welfare, and old age provision. These have been replaced today by modern forms of care (Studer, 1998).

For certain social movements, social aspects were always part of a holistic understanding of agriculture. Important representatives of this orientation can be found, for example, in anthroposophic circles, but also in many other movements based on ecological, ethical, religious, and philanthropic motivations. Limbrunner (2003), for example, refers to the potential represented by the intensification of the relationships between organic farming and social work. In addition, as is typical of Switzerland's decentralized system, numerous grassroots and locally grown solutions to social emergencies existed in the past and continue to exist today: indeed, the attitude was and

\footnotetext{
${ }^{1}$ For further information, see The Community of Practice Farming for Health website: https://farmingforhealth.wordpress.com.

${ }^{2}$ COST (European Cooperation in Science and Technology) is an EU framework supporting cooperation among scientists and researchers across Europe. For further information see www.cost.eu.
} 
International Journal of Child, Youth and Family Studies (2015) 6(3): 440-457

is that, where possible, solutions should be community-based and social-welfare solutions should be organized on a decentralized basis. As the current debate concerning the history of the Verdingkinder [contract children] - indentured child labourers - shows, it is necessary to create transparent, good quality general conditions for these services (Heller, Avvanzino, \& Lacharme, 2005).

From an agricultural perspective, care farming can be understood as a structural diversification strategy ("para-agriculture”) adopted by farming households/operations. Agricultural operations in Switzerland are strongly dominated by family operations. Over $80 \%$ of farmers live on their own farms, usually with their family members (Bundesamt für Landwirtschaft, 2007). The traditional full-time holding, that is, the type of farm where core agricultural production is the sole source of income and the members of the household work on the farm if needed, accounts for barely one quarter of all agricultural operations in Switzerland (Saxer, 2007). The majority of farm managers and their partners have embraced diversification strategies such as labour market integration: in $59 \%$ of agricultural operations in Switzerland, the farm manager, his or her partner, or both, rely on external employment. In addition to agricultural diversification, there are indications that structural diversification is an increasing factor in farming operations: households/operations are diversifying in sectors that are not in the core area of agricultural production. These activities are referred to in Switzerland as para-agriculture and include such activities as direct marketing, the processing of agricultural products, agritourism, handcrafts, wood processing, and certain forms of energy production. Internal diversification arises in approximately two-fifths of farming operations. (Saxer, 2007). There are few reliable data on the scale and nature of the social services provided within the agriculture sector in Switzerland. The existing data sources tend to focus on the farming operation and its core production area; the varied income-generating pursuits of the household members are recorded with few details, if at all. In the Federal Statistical Office's (SFSO) agricultural farm census of 2005, in a supplement to the farm structure questionnaire, a randomly-selected sample was presented with a short questionnaire on the pursuit of activities in para-agriculture (Bundesamt für Statistik, 2005). Although this survey extends the focus to activities with economic impacts on the farm, it does not include those within the farm household. Information about the scope of care-farming services and the persons who provide them, or a more detailed description of the activities and of the nature of their integration into the farm are not available. Limitations also exist in relation to another data source: the central evaluation of accounting data by the Agroscope Reckenholz-Tänikon (ART) research station. ${ }^{3}$ Although different para-agricultural activities are surveyed here in the context of accounting data, they are only recorded if they form part of the farm's operational activities. There is scope for the inclusion of care-farming activities in the accounting; however, smaller operations are generally not covered by the central evaluation of accounting data and the nature of the services provided is not recorded in detail.

Having specified the context for the implementation of care-farming activities in the above-presented accounts, we shall now ask what the concrete developments in

\footnotetext{
${ }^{3}$ For further information see: http://www.agroscope.admin.ch/betriebswirtschaft/04362/index.html?lang=de
} 
International Journal of Child, Youth and Family Studies (2015) 6(3): 440-457

Switzerland look like. In the research project presented below, attention is also focused on the target group comprising children and adolescents. To appreciate the presented results in their historical context, we believe that it will be helpful to review the foster care system in Switzerland. The first central actors in the foster care system, who also play a key role in the context of social services in agriculture, are presented here.

\section{Foster care in Switzerland}

Foster care is a central component of child and youth welfare in Switzerland; however, empirically-founded knowledge on the sector is scant. No national statistics are recorded on this topic; for example, it is not known how many children and adolescents live with foster parents (Zatti, 2005). Based on the data from the 1990 census, the number of foster children has been estimated for almost 15 years at 15,000 (Zatti, 2005; Shuler, 2013). Similarly, there are no current data on the demographics and socio-economic backgrounds of foster families. A study on foster families undertaken some time ago in the canton of Zurich found that one-third of foster children lived with relatives and, hence, two-thirds were placed in non-kinship foster homes (Juhasz \& Sunitsch, 1996).

In recent years, only a few studies have been published that focus on the fostering process in Switzerland, on the participation of children and parents (Arnold, Huwiler, Raulf, Tanner, \& Wicki, 2008; Wigger \& Stanic, 2012), and on the perception and impact of foster situations (Gassmann, 2010). Interest in the exploration of care farming as a diversification strategy for farming families and as an additional possibility for accommodating foster children and adolescents has clearly increased in recent years (see Hodel, 2012; Karli, 2007; Stohler \& Werner, 2013).

The history of foster care in Switzerland has not been dealt with systematically (Zatti, 2005). The first studies examining the practices of the authorities and the injustices suffered by the victims of the system of contract children were published a few years ago (e.g., Freisler-Mühlemann, 2011; Leuenberger \& Seglias, 2008; Leuenberger, Mani, Rudin, \& Seglias, 2011). Under that system, in the $19^{\text {th }}$ century and early decades of the $20^{\text {th }}$ century, authorities frequently placed orphans, children of divorced parents, illegitimate children, and children from poor backgrounds with farming families for a subsistence payment. The children were forced to work hard for their keep and often suffered violence and injustice (see, e.g., Leuenberger \& Seglias, 2008).

Residential and foster care in Switzerland has undergone considerable change since the 1970s; for instance, a basic distinction is now made between "traditional" and "professional” foster families (Zatti, 2005). Whereas traditional foster families do not have any specific training, in professional foster families at least one of the parents has undergone training in social services or special needs education, and the family income is mainly derived from caring for foster children. The "networked" foster families, a third type (Zatti, 2005, p. 11) that developed in the 1990s, can be described as semiprofessional. Unlike the other two types, networked families are monitored and supported by a family placement organization (FPO) (Zatti, 2005). There is no overview available showing how many of each of the different types of foster family there are in Switzerland. 
International Journal of Child, Youth and Family Studies (2015) 6(3): 440-457

As is the case in other European states (EveryChild, 2011), there seems to be an increasing trend towards family placements in the area of child and youth foster care in Switzerland, although precise data are not available; one possible cause is the structural shift that is forcing families in agriculture and small business to secure additional income streams (Zatti, 2005). Because farms often have the necessary space, the provision of foster-care places is an obvious option for farming families. In Zatti's view, this development presents an opportunity for the foster-care sector. "To a certain extent, this trend can offset the lack of suitable foster families observable in some locations under the condition that the families are suitably prepared, expertly monitored and professionally supported in their work" (p. 31).

The FPOs offer a range of services in foster care and have developed into a separate area of foster care over the past two decades (Keller, 2013). The first organizations were established in the 1990s and, although the exact number is not known, it is estimated that at least 70 such organizations exist in German-speaking Switzerland (Keller, 2013).

The FPOs fulfil important tasks in the area of child and youth welfare on behalf of the authorities and referring bodies, and "have a major influence on the safe and development-promoting placement” (Keller, 2013, p. 113) of children and adolescents with foster families. They are responsible for, among other things, the recruitment of foster families and referral of foster places, and offer services for foster families and for foster children, such as regular visits and advisory discussions. An FPO usually has a particular focus area and tailors its services to children or adolescents, or to a particular duration (long- or short-term placement) or to a function of the care situation (time-out, temporary or emergency placement, or assessment) (Keller, 2013).

Since no binding quality standards apply to the activities of the FPOs at the national level, the question regarding their quality has been a matter of concern to experts in the field for some time. For example, various organizations joined forces to establish an Interessengemeinschaft für Institutionelle Pflegeplätze [Interest Group for Institutional Foster Placements] and the Expert Association for Social and Special Needs Education (Integras) has developed a quality label for FPOs, which can be acquired through a certification process (Keller, 2013). Other organizations also provide labels that can be obtained by the FPOs (Spindler, 2011). Similarly, some individual cantons, such as Bern, have formulated guidelines for the activities of FPOs (Wydler, Stohler, Christ, \& Bombach, 2013).

Legal aspects. Child and youth welfare and, hence, foster care in Switzerland are based on the United Nations Convention on the Rights of the Child, which was ratified by Switzerland in 1997 (Arnold et al., 2008). In addition, the Federal Constitution of the Swiss Confederation (Art. 11) guarantees children and adolescents "the right to the special protection of their integrity and the encouragement of their development”. The legal basis for foster care is provided by articles 307-317 of the Swiss Civil Code. These provide the basis for the Ordinance of 19 October 1977 on the Placement of Children in Foster Care (Pflegekinderverordnung, PAVO, SR 211.222.338). This ordinance contains basic provisions, which the cantons are responsible for implementing (Zatti, 2005). Swiss foster care was long criticized for its lack of regulations on the protection of children and adolescents in foster placements, and the ordinance was partly revised as a result. The 
International Journal of Child, Youth and Family Studies (2015) 6(3): 440-457

new provisions have been in force since early 2013 and January 2014 (Eidgenössisches Justiz- und Polizeidepartement, 2012). A central feature of the revised legislation is that persons or families in Switzerland who would like to provide foster placements for children require authorization from the competent authority and are subject to the supervision of this authority (Art. 4 PAVO). Moreover, requirements for the activities of the FPOs also came into force for the first time on 1 January 2014 (Art. 20a- f PAVO); these organizations had been active hitherto in various cantons without being subject to any specific legislative conditions. The revised legislation now includes a registration obligation for persons and organizations that provide services in the area of family care, whether for payment or free of charge. While corresponding provisions existed in individual cantons, some cantons had to develop new solutions as a result (Wydler et al., 2013).

A further innovation in the area of child protection in Switzerland that also affects foster care is the introduction of professional child-protection authorities on 1 January 2013. Up to the end of 2012, the municipal guardianship authorities were responsible for decisions in the area of child and adult protection in German-speaking Switzerland. Except in the larger cities, the members of these lay authorities frequently did not have the necessary resources for the work they carried out (Zatti, 2005). The law now stipulates that the responsibility for decisions in the area of child and adult protection now rests with a regional expert authority consisting of at least three members. The cantons are responsible for the appointment and implementation of the expert committees (Art. 440 Swiss Civil Code). As the overview provided by Fassbind (2013) shows, the cantons availed themselves of their organizational autonomy when it came to the implementation of the new authority structure. With the new Child and Adult Protection Act [Kindes- und Erwachsenenschutzgesetz] coming into force, the number of competent authorities was significantly reduced. Up to the end of 2012, approximately 1,420 guardianship authorities were responsible for decisions on child and adult protection in Switzerland. Since January 2013, there have been approximately 148 professional expert authorities, which are now known as child- and adult-protection authorities [Kindes- und Erwachsenenschutzbehörde, KESB]. According to Fassbind (2013), the professionalization of these authorities and the accompanying reduction in their number is an important attainment.

\section{Care farming in Switzerland}

The stronger orientation of agriculture towards its constitutional objectives could result in the emergence of greater respect for the provision of care services. ${ }^{4}$ Today, agriculture contributes to the integration and participation of various target groups, creates and maintains job opportunities in rural regions in the context of a multi-income strategy, and contributes to the decentralized settlement of the country. In the area of

\footnotetext{
4 The constitutional objectives for agriculture include security of supply, the conservation of natural livelihoods, the preservation of the cultivated landscape and decentralized settlement. If the New Agricultural Policy places greater emphasis on the positive external effects of agriculture (ecology, biodiversity, but also the inclusion services provided by agriculture), care farming services also appear to better fit into the framework of the defined targets of agricultural policy.
} 
International Journal of Child, Youth and Family Studies (2015) 6(3): 440-457

social services, care farmers provide important services that can have positive external effects. However, little is known of the scope and impact of these services.

It is obvious, however, that care farming can only constitute a small element of a multifunctional agriculture sector. It is a niche activity, but nevertheless presents considerable potential. Care farming is practised more frequently on organic farms and, in many cases, it forms part of a specific view on how sustainable farming should be implemented. Social aspects are a very important element of this viewpoint. Organic farming was practised by $25 \%$ of the sample of care farms surveyed (Wydler, Widmer, \& Christ, 2010a).

Only fragmentary empirical data are available on the diffusion and scale of care farming in Switzerland. According to the study carried out by Wydler and Gairing (2010), at least one percent of agricultural family operations offer care services; children, adolescents, and disabled people are the main target groups. The evaluations show that the families providing care report merely average satisfaction rates from their involvement, which entails time pressure and psychological challenges. This is due in part to unsatisfactory legal and societal conditions: their work tends to be low in status, their professionalism is underdeveloped, and finances often lack transparency (Wydler et al., 2010b).

\section{Method}

\section{Objectives of the study}

The aim of the study was to examine the provision of social services by farms through a system analysis: an overview of the most important actors, the legal provisions, processes, requirements, tasks, and competencies. Based on this analysis, we also attempt to project the future development of care farming.

The main objectives of the study were:

- to provide an actor-based and exemplary system analysis of the current situation in relation to placements in farming families by means of a case study in each of three cantons: Berne, St. Gallen, and Zurich;

- to record and assess developments and changes in care farming caused by the new Child and Adult Protection Act [Kindes- und Erwachsenenschutzgesetz] and identify potential opportunities and risks associated with the new system; and

- to integrate and compare multiple perspectives as a basis for identifying development potential in the care farming area, for formulating strategies and measures to promote the objectives of care farming, and to assess the risks of the different approaches.

The study did not focus on the perspectives of the people who are the subjects of social services activity in the agriculture sector, nor those of the farming families who provide these services or wish to do so. This would require a far more complex study design. Hence, the analysis of the perspectives of the service users and providers was expressly not an objective of the study. 
International Journal of Child, Youth and Family Studies (2015) 6(3): 440-457

\section{Target group}

The study examined so-called civil law foster placements, that is, placements arising on the instigation of guardianship authorities or, from 1 January 2013 onward, the child and adult protection authorities, in accordance with the Swiss Civil Code of 10 December 1907 (Schweizerisches Zivilgesetzbuch, SR 210) and the Ordinance of 19 October 1977 on the Placement of Children in Care (Pflegekinderverordnung, PAVO, SR 211.222.338).

This analysis relates to the two most important target groups of care farming: children and adolescents placed in foster care, and people with disabilities subject to guardianship [Beistandschaft] (Wydler \& Gairing, 2010). As a result, many of the current target groups of care farming were not considered, such as persons subject to criminal law measures, and placements made in relation to health therapies, rehabilitation, or voluntary time-outs. The reason for this limitation is that each type of placement has its own authorities and sources of financing.

The central findings for the target groups, children and adolescents, are presented below. This paper does not cover the specific situation of persons with disabilities.

\section{Implementation of the study}

The study was carried out from January to October 2013. The project was supported by an advisory group consisting of representatives from the agriculture sector, the child and adult protection authorities, the Jugendamt [Youth Welfare Service], the foster care system, Integras, and the disabled self-help sector. Four meetings were held with the advisory group, at which the intermediate findings were discussed and the project was further developed and substantiated with the help of the different perspectives of the group members who had practical experience of the foster care system.

\section{Research methods}

A qualitative research approach was selected. A system analysis was carried out for each of the three cantons, based on a document analysis of organizational, legal, and institutional conditions and policies conducted through Internet research and discussions. The situation in relation to care farming in the relevant cantons was identified with the help of information on the number of placement organizations, an estimate of the number of care farmers, a review of traditional policies, and an estimate of the scope of the services currently provided. Central networks and performance structures were also identified with the help of qualitative methods. This information was complemented by qualitative interviews with selected representatives of child- and adult-protection authorities [Kindes- und Erwachsenenschutzbehörden, KESB]. Interviews were carried out with three FPOs and four KESBs in the cantons Berne, St. Gallen, and Zurich. The interview partners were selected and solicited on the basis of the document analysis.

\section{Results}

The study showed that placements of children and adolescents in foster families in the agriculture sector, known as care farming, are carried out in the official foster care 
International Journal of Child, Youth and Family Studies (2015) 6(3): 440-457

context, but that specific regulations relating explicitly to care services in agriculture do not exist in Switzerland.

Foster care is organized at the federal level in Switzerland. Hence, the most important general conditions are defined at the national level and the cantons and municipalities are responsible for their implementation.

There have been important changes to the Swiss national legal basis of foster care which are also of importance for care farming. For example, the new provisions adopted in the context of the partial revision of the Ordinance on the Placement of Children in Care (PAVO) entered into force in early 2013 and 2014. In terms of the placement of children and adolescents in agriculture, the legislative innovations include new requirements for the providers of services in the area of family care (the FPOs). Regulations governing their complex and demanding activities were previously lacking at the national level.

The research in the three cantons shows that the FPOs play an important role in the placement of children and adolescents in agriculture. In one canton, in particular, there are FPOs that specialize in the referral of foster places in farming families. However, the exact number of FPOs in the canton in question is still unknown as authorization is required only for larger FPOs (as of late 2013).

With the enactment of the revised PAVO and the new obligation to register and monitor FPOs, each canton will be informed in future about the number of organizations active in the canton and about the families with which they work. Statistical recording of the socio-economic background of the foster families would help to make care farming or placements in agriculture more visible and better understood. The extent to which this is being done by the cantons is not known.

The first conversations with representatives of the KESBs from the three cantons revealed a basically neutral attitude to these placements in agriculture. Important criteria for a placement include securing the well-being of the child and achieving an acceptable fit between the child and foster family. Explicit indications for placements in agricultural settings were not mentioned by the interviewed representatives of the authorities. Hence, from the perspective of the KESBs, placements in agricultural settings are possible options that can be used as required. All of the interviewed KESB members reported positive experiences with FPOs and stressed their importance for the success of placements. It is not currently possible to estimate the extent to which placement practices and the allocation of authorizations to foster families will ultimately change through the professionalization of the authorities. Decisions are based on the substantiated proposals of the assessing social services, whose experience and attitudes with regard to placements in agricultural settings went unrecorded until recently.

The interviews with representatives of the FPOs show that farming families have considerable interest in offering social services on their farms. The FPOs check the suitability of the families; the representatives indicated in the interviews that only some families are deemed suitable. The organizations' own selection criteria are assessed as strict and are also regulated based on cantonal requirements. The interviewed representatives of the FPOs and KESBs draw attention to the fact that the topics of religiosity and an additional income stream are repeatedly raised in connection with the 
International Journal of Child, Youth and Family Studies (2015) 6(3): 440-457

motivation of the families in offering foster places. The FPOs' reaction to this varies. The interested families not only have to pass the FPOs' selection process: they must also be authorized by the KESBs. In general, the examined FPOs value professionalism and quality. Evaluations or studies on the practice of the FPOs by independent assessors do not yet exist, however. The acceptance of foster children makes significant demands on the families. According to the interviewed KESB representatives, the skills required are also available in agricultural settings, but are not qualitatively better or do not arise more frequently there than in other environments. Conversely, critical arguments against placements in agricultural settings or rural areas were presented, in particular by individual representatives of FPOs, who cited the lack of therapeutic services or special schools in rural areas, and listed sources of danger to be found on farms.

It emerged from the interviews with the representatives of the FPOs and KESBs that it is primarily adolescents who are placed in agricultural settings, usually in the context of time-outs or temporary solutions, and that the farm criterion is not relevant for the long-term placement of younger children. Time-outs generally tend to arise for educational or legal reasons.

\section{Conclusion and Outlook}

The analysis that was carried out primarily outlines the context in which care farming arises in the area of Swiss foster care. Care farming is integrated into the existing system but it remains relatively invisible and poorly understood. Cost arguments could represent an important background factor and driver for care farming. In this regard, the debates and comparisons about foster care and residential placements will intensify in the future. The expert discussions show that, in practice, a lot of experience-based knowledge is available that has not been systematically analyzed. The perspectives of the affected children and adolescents are also unrecorded. Further research on support for foster children and, in particular, on the efficacy of agricultural settings is required to ensure visibility and quality in this field. 
International Journal of Child, Youth and Family Studies (2015) 6(3): 440-457

\section{References}

Arnold, C., Huwiler, K., Raulf, B., Tanner, H., \& Wicki, T. (2008). Pflegefamilien- und Heimplatzierungen: Eine empirische Studie über den Hilfeprozess und die Partizipation von Eltern und Kindern. Zürich/Chur: Verlag Rüegger.

Braastad, B.O., Gallis, C., Sempik, J., Senni, S., \& van Elsen, T. (2007). COST Action 866 "Green care in agriculture" - A multi-disciplinary scientific network. In C. Gallis (Ed.), Green care in agriculture: Health effects, economics and policies (pp. 13-24). Vienna: University Studio Press.

Bundesamt für Landwirtschaft. (2007). Agrarbericht 2007 des Bundesamtes für Landwirtschaft. Bern: RDV.

Bundesamt für Statistik (Hrsg.). (2005). Die Landwirtschaft in den Kantonen: Ergebnisse der regionalen Gesamtrechnungen. Neuchâtel: OFS.

Christ, Y., Widmer, S., \& Wydler, H. (2010). Care farming: Potenziale sozialer Dienstleistungen in der Landwirtschaft (Schlussbericht Workshop 1 - 3). Retrieved from https://docs.google.com/viewerng/viewer?url=http://www.greencare.ch/images/st ories/pdf/schlussbericht_sofa1.pdf

Condrau, V., Ketterer, L., Kleiner, J., Siegrist, D., Schüppel, S., \& Wasem, K. (2012). Neue Green Care Erholungsangebote in der Landwirtschaft. Ein Projekt im Rahmen der COST Aktion 866 "Green care in Agriculture". Rapperswil: Instituts für Landschaft und Freiraum der HSR Hochschule für Technik Rapperswil.

Dessein, J. (Ed.). (2008). Farming for health: Proceedings of the community of practice farming for health. November 2007, Ghent, Belgium. Merelbeke, Belgium: ILVO.

Di Iacovo, F., \& O'Connor, D. (Eds.). (2009). Supporting policies for social farming in Europe: progressing multifunctionality in responsive rural areas. Firenze: ARSIA.

Driest, P.F. (2006). Long-term care in Europe: an introduction. In J. Hassink \& M. van Dijk (Eds.), Farming for health (pp. 101-106). Netherlands: Springer. http://dx.doi.org/10.1007/1-4020-4541-7_8

Eidgenössisches Justiz- und Polizeidepartement. (2012). Klare Regeln für Organisationen zur Vermittlung von Pflegekindern, Medienmitteilung. Retrived from http://www.ejpd.admin.ch/ejpd/de/home/aktuell/news/2012/2012-0222.html

EveryChild. (2011). Scaling down: reducing, reshaping and improving residential care around the world. (Positive care choices: Working Paper 1). London: EveryChild. 
International Journal of Child, Youth and Family Studies (2015) 6(3): 440-457

Fassbind, P. (2013). Kantonale und innerkantonale Buntheit. Die Organisation der Kindes- und Erwachsenenschutzbehörden in der Schweiz. SozialAktuell, Nr. 1, 15-17.

Freisler-Mühlemann, D. (2011). Verdingkinder - ein Leben auf der Suche nach Normalität. Bern: Hep Verlag AG.

Gassmann, Y. (2010). Pflegeeltern und ihre Pflegekinder: empirische Analysen von Entwicklungsverläufen und Ressourcen im Beziehungsgeflecht. Münster / New York / München / Berlin: Waxmann.

Goris, K., \& Dessein, J. (2007). Social farming in Flanders and Belgium: State of the art - version April. (SoFar Project). Retrieved from http://sofar.unipi.it/index_file/State_of_the_Art_Flanders\%5b1\%5d.pdf

Hassink, J., \& van Dijk, M. (2006a). Farming for health across Europe: Comparison between countries, and recommendations for a research and policy agenda. In J. Hassink \& M. van Dijk (Eds.), Farming for health (pp. 347-357). Netherlands: Springer. http://dx.doi.org/10.1007/1-4020-4541-7_22

Hassink, J., \& van Dijk, M. (Eds.). (2006b). Farming for health: Green-care farming across Europe and the United States of America. Netherlands: Springer. http://dx.doi.org/10.1007/1-4020-4541-7

Haubenhofer, D., Demattio, L., \& Geber, S. (2012). Analyse unterschiedlicher Green Care Finanzierungsmodelle in Österreich und dem europäischen Ausland: Ein Bericht für das ländliche Fortbildungsinstitut und die Landwirtschaftskammer Wien. (Ausgeführt im Rahmen des Projektes 'Green Care - Wo Stadtmenschen aufblühen'). Wien.

Haugan, L., Nyland, R., Fjeldavli, E., Meistad, T., \& Braastad, B.O. (2006). Green care in Norway: Farms as a resource for the education, health and social sector. In J. Hassink \& M. van Dijk (Eds.), Farming for health (pp. 109-126). Netherlands: Springer. http://dx.doi.org/10.1007/1-4020-4541-7_9

Heller, G., Avvanzino, P., \& Lacharme, C. (Eds.). (2005). Enfance sacrifiée. Témoignages d'enfants placés entre 1930 et 1970. Lausanne: Haute école de travail social et de la santé.

Hine, R., Peacock, J., \& Pretty, J. (2007). Care farming in the UK: Recent research findings on the scope and range of care farms in the UK. In C. Gallis (Ed.), Green care in agriculture: Health effects, economics and policies (pp. 123-136). Vienna: University Studio Press. 
International Journal of Child, Youth and Family Studies (2015) 6(3): 440-457

Hine, R., Peacock, J., \& Pretty, J. (2008). Care farming in the UK: Evidence and opportunities (Report for the National Care Farming Initiative [UK]). Retrieved from http://www.carefarminguk.org/sites/carefarminguk.org/files/UK\%20Care\%20Far ming\%20Research\%20Summary.pdf.pdf

Hodel, A. (2012). Soziale Landwirtschaft. Soziale Dienstleistungen in der Landwirtschaft im Kanton Bern. Bachelor Thesis: Fachhochschule Nordwestschweiz. Hochschule für Soziale Arbeit.

Juhasz, A., \& Sunitsch, C. (1996). (Un-)Typische Familien. Pflegefamilien im Kanton Zürich - eine empirische Untersuchung. Zürich: Eigenverlag.

Kalisch, M., \& van Elsen, T. (2007). Social farming in Germany: Outcomes of the national experts meeting organised within the European Sofar Project. In C. Gallis (Ed.), Green care in agriculture: Health effects, economics and policies (pp. 207220). Vienna: University Studio Press.

Karli, A. (2007). Bauernfamilie als sozialpädagogische Lebenswelt. Theoretische und praktische Überlegungen zu Anforderungsprofil und Qualifizierung von Bauernfamilien. (Bachelorarbeit). St. Gallen: Hochschule für Angewandte Wissenschaften.

Keller, A. (2013). Familienplatzierungsorganisationen (FPO). In Integras (Ed.). Leitfaden Fremdplatzierung (pp. 113-123). Zürich: Eigenverlag.

Leuenberger, M., Mani, L., Rudin, S., \& Seglias, L. (2011). "Die Behörde beschliesst" Zum Wohl des Kindes? Fremdplatzierte Kinder im Kanton Bern 1912-1978. Baden: hier und jetzt, Verlag für Kultur und Geschichte.

Leuenberger, M., \& Seglias, L. (Eds.). (2008). Versorgt und Vergessen. Zürich: Rotpunktverlag.

Limbrunner, A. (2003). Grüne Sozialarbeit. Boden unter den Füssen oder: Macht Landluft frei? Ökologie in der Sozialen Arbeit. Ein Blick auf eine zukunftsweisende Praxis. Sozialmagazin, 28, 12-19.

Limbrunner, A., \& van Elsen, T. (Eds.). (2013). Boden unter den Füssen. Grüne Sozialarbeit - Soziale Landwirtschaft - Social Farming. Weinheim und Basel: Beltz Juventa.

Mayer, E., \& van Elsen, T. (2005). Soziale Landwirtschaft als Integrationsmöglichkeit von Naturschutzmassnahmen. Der Therapiehof „Helle Platte“ als Praxisbeispiel. In T. van Elsen (Ed.), Einzelbetriebliche Naturschutzberatung - ein Erfolgsrezept für mehr Naturschutz in der Landwirtschaft. Beiträge zur Tagung vom 6.-8. Oktober 2005 in Witzenhausen (187-194). Witzenhausen: FiBL Deutschland e.V. 
International Journal of Child, Youth and Family Studies (2015) 6(3): 440-457

Pawelczyk, E. (2006). Farming and social-care combinations in Poland. In J. Hassink \& M. van Dijk (Eds.), Farming for health (pp. 271-288). Netherlands: Springer. http://dx.doi.org/10.1007/1-4020-4541-7_19

Saxer, M. (2007). Nebentätigkeiten von bäuerlichen Familien in der Schweiz. Neuchâtel: Bundesamt für Statistik.

Sempik, J., Hine, R., \& Wilcox, D. (Eds.). (2010). Green care: A conceptual framework. A report of the working group on the health benefits of green care. Loughborough: Loughborough University.

Shuler, B. (2013). Pflegekinderhilfe. In Integras (Ed.), Leitfaden Fremdplatzierung (pp. 89-112). Zürich: Eigenverlag.

Spindler, C. (2011). Eiertanz um Labels und Standards. Familienplatzierende Organisationen brauchen klare Qualitätskriterien gegen den Wildwuchs in der Branche SozialAktuell, 7/8, 10-11.

Stohler, R., \& Werner, K. (2013). Pflegeplätze für Kinder und Jugendliche auf Bauernhöfen: Wenn Pflegekinder auf Bauernhöfen leben. Netz Fachzeitschrift Pflegekinder, 2, 28-31.

Studer, B. (1998). Soziale Sicherheit für alle? Das Projekt Sozialstaat 1848-1998. In B. Studer (Ed.), Etappen des Bundesstaates: Staats und Nationsbildung der Schweiz. (pp. 159-168). Zürich: Chronos.

Vadnal, K. (2007). Social/care farming in Slovenia: A new scenario of sustainable rural development. Ljubljana: University of Ljubljana.

Wiesinger, G. (Ed.). (2011). Green Care in Landwirtschaft und Gartenbau. (Resumee der COST Action 866 "Green Care in Agriculture"). Wien: Bundesanstalt für Bergbauernfragen.

Wigger, A., \& Stanic, N. (2012). Projektbericht Kinder wirken mit. Empfehlungen zur Förderung der Mitwirkung in der ausserfamiliären Betreuung. Rorschach: Institut für soziale arbeit. Available from http://pflegekinder.ch/Dokumente/Projektbericht.pdf

Wydler, H., \& Gairing, M. (2010, July). Care farming in Swiss farm households Gender aspects in pluriactivity. 9th European IFS Symposium. Vienna, Austria. Available at http://www.greencare.li/images/stories/pdf/care\%20farming\%20in\%20swiss\%20f arm\%20households.pdf

Wydler, H., \& Picard, R. (2010). Care Farming: Soziale Leistungen in der Landwirtschaft. Agrarforschung Schweiz, 1(1), 4-9. 
International Journal of Child, Youth and Family Studies (2015) 6(3): 440-457

Wydler, H., Widmer, S., \& Christ, Y. (2010a). Care farming in Switzerland. In T. van Elsen, F. Di Iacovo, \& J. Hassink (Eds.), Policies of green care in agriculture. COST (in preparation).

Wydler, H., Widmer, S. \& Christ, Y. (2010b). Soziale Dienstleistungen in der Schweizer Landwirtschaft: Care Farming. Zurich: Research Station Agroscope ReckenholzTänikon ART, Zürich University of Applied Sciences, Institute for Environment and natural Resources ZHAW. COST-Beitrag.

Wydler, H., Stohler, R., Christ, Y., \& Bombach, C. (2013). Care Farming - eine Systemanalyse. Schlussbericht. Zurich: Zürcher Hochschule für Angewandte Wissenschaften: Life Sciences und Facility Management, Umwelt und Natürliche Ressourcen. Soziale Arbeit, Forschung und Entwicklung. Available from http://www.sozialearbeit.zhaw.ch/fileadmin/user_upload/soziale_arbeit/Forschung /Forschungsberichte/Kindheit_Jugend_Familie/Care_Farming_Schlussbericht.pdf

Zatti, K.B. (2005). Das Pflegekinderwesen in der Schweiz. Analyse, Qualitätsentwicklung und Professionalisierung. Expertenbericht im Auftrag des Bundesamtes für Justiz. Available from https://www.bj.admin.ch/dam/data/bj/gesellschaft/gesetzgebung/archiv/kinderbetr euung/ber_pflegekinder-d.pdf 